\title{
Clowns, the Circus and Avant-garde Theatre
}

\author{
Christopher Innes \\ York University, Canada
}

\begin{abstract}
Building on the ritual element associated with the avant-garde, the argument is that in contrast to the predominant concept of avant-garde artists as esoteric and elitist, from the beginning of the movement in the 1890s avant-garde artists chose the most popular form of expression in conjunction with their esthetic experimentalism and political radicalism. Focusing specifically on theatre, although also referencing painters and musicians, the links with clowns and circus carry through from Satie in France, Reinhardt and Brecht in Germany, through Brook and Genet, to an internationally representative pair: Lepage and Ciulli, demonstrating how this popular imagery has already changed.
\end{abstract}

Keywords: Circus, Avant-garde, postmodernism

\section{Introduction}

The writer's interest in the Avant-garde goes back over 30 years, to before 1981, when he wrote a book on Holy Theatre: Ritual and the Avant Garde. That book, taking its title from Antonin Artaud, focused on the religious elements of experimental and political art through the $20^{\text {th }}$ century. But recently he has begun to evaluate the work of the avant-garde differently, seeing really important roots in popular performance culture, which offsets the general view that avant-garde artists are elitist and deliberately difficult to comprehend.

What people have to realize is that, from the very beginning, avant-garde artists drew on the most popular culture: from Alfred Jarry's roots in Grand Guignol puppetry (as in the 1896 Ubu Roi), to cabaret, as with the French nightclub the Chat Noir — a hive of avant-garde activity at the time - where Eric Satie performed as pianist. Satie wrote music for a pantomime by Jules Dépaquit, titled Jack-in-the-box (which Satie, tellingly, called a "clownerie"). Satie also happens to be seen as a precursor to the Theatre of the Absurd — and it's no accident that Beckett's plays are full of clown figures (from Didi and Gogo in Waiting for Godot, through his authorial alter ego in Krapp's Last Tape, to the Bim and Bom of What/Where, named after Russian clowns from the 1920s). The line runs right up to performance artists like the Canadian Robert Lepage, or the Italian/German director Roberto Ciulli — whom I want to focus on today.

A brief historical overview demonstrates that Cabaret, Clowns and the Circus are truly popular arts: downmarket; sand and sawdust; fairground songs and crude red noses; sexuality and alcohol; the widest appeal for the lowest common denominator, as memorably represented by Marlene Dietrich in Der Blaue Engel. Yet throughout the whole avant-garde movement artists embraced Circus (and its nightclub equivalent, Cabaret) with passion. One might well ask why these artists adopted such common forms of expression. It was partly at least because of politics, because adopting the popular and anti-intellectual was a slap-in-the-face to bourgeois

Christopher Innes , Canada Research Chair, Distinguished Research professor, York University.

Correspondence concerning this article should be addressed to York University, Canada. Email:cinnes@yorku.ca. 
artistic pretensions - but also partly because this so-called "light-entertainment" disguised social criticism from repressive authorities. The German Kaiser had declared: “Art is an arm of government”. So in order to attack, or even simply criticize the system, writers were forced to find ways didn't count as art. Particularly the Circus and Cabaret — specifically because, as "popular" and "unartistic" nightclub entertainment, it allowed a certain freedom for satire and trenchant social commentary. So Max Reinhardt's "Noise and Smoke" (Schall und Rauch) Cabaret, founded in 1901 in Berlin as an unofficial part of the Deutsches Theater, and after 1919 in the cellar of Reinhardt's Grosses Schaupielhaus, were all dressed up as clowns and used circus imagery. Similarly, it is worth noting that as a youth the German Expressionist playwright, Frank Wedekind, had worked backstage for circuses in Paris as a young man; and his well-known Lulu plays had a circus frame.

\section{Literature Review}

The Avant-garde tends to be considered esoteric, stylistically challenging and difficult. But in fact from their very beginnings, both Dada and Brecht based their work on Circus and Cabaret. There's a well-known photograph of the young Brecht, performing (on guitar) with the Munich comedian Karl Valentin (on Tuba) and an iconic white-faced clown in Munich, 1919. This is a traditional fairground "Bänkelgesang" — a performance of a horror-story or "Moritat" (illustrated by a painting on the front of the trestle showing a clown being run down by a car full of toffs) with strongly political overtones. As the photo shows, this fairground cabaret already features the major techniques that were to mark Brecht's epic style: third-person acting (in the figure of the top-hatted "compère", who is in fact a woman in male dress), as well as a montage of short scenes, and the use of a half-curtain. Indeed, the Moritat becomes the theme song for Brecht's most experimental early piece, Die Driegröschenoper: in Mackie Messer — as well as Pirate Jenny. As the cover of Kurt Weill's original score for Die Driegröschenoper declared, this was the epitome of popular culture: "Music for All”. Valentin also took on the posture and costume of an archetypal clown figure for his cabaret performances; and there are photos of him on a cabaret stage with clown hat and bicycle - while playing on the same clown imagery, it was Valentin who suggested that Brecht use whiteface for the characters in his plays; and indeed Brecht adopted this for almost all his early productions.

Of course, it is not just avant-garde theatre that draws on the circus. Painting - that most modernist of arts - does too. Indeed, the circus forms a major theme for various avant-garde painters. Chagall's numerous paintings of the circus and its performers range from equestrian dancers and clowns, through acrobats to sad-faced clowns. Similarly one of Picasso's earliest paintings is a tribute to the circus, portraying a family in clown costumes, while Picasso's one stage work, Parade performed in 1917, has a back-drop that shows a circus horse and paraphernalia of the circus ring, as well as harlequin costumes. In fact this show was a perfect conglomeration of the avant-garde - with performers from the Ballets Russes and choreography by Massine, music by Eric Satie, libretto by Jean Cocteau — and the circus elements are iconographic for avant-garde art at its most intense period.

Peter Brook and Jean Genet are direct inheritors of this line of development, with Brook's iconic production of Midsummer Night's Dream being performed in a circus format with actors on stilts, on trapezes and as acrobats, including (for the character of Bottom) a typical clown-nose - while one of Genet's most murderous and political plays, The Blacks, was subtitled A Clown Show. All this leads straight to contemporary avant-garde performer/directors like Robert Lepage and Roberto Ciulli, who can be seen as representative of the whole international aspect of this post-modern movement: Lepage being French Canadian and performing 
his pieces all over Europe as well as in Las Vegas, while Ciulli is Italian working in Germany, and taking his work across the Middle East and Asia

Roberto Ciulli, who founded and runs the Theater am Ruhr, has made a film titled Clowns in the Night, representing society as sad circus performers behind bars, with bulbous noses that have become a repetitive icon of his productions. For example, in his 1987 staging of Die Dreigroschenoper, where Ciulli himself took several of the minor roles, he played the jailer wearing a large round red nose: one of the recurrent costume pieces at Theater an der Ruhr, which recurs in his productions of Peter Handke's Kaspar, (also 1987), Goldoni's Teatro Comico (1993), the 1997 Pinocchio Faust, or his 2005 adaptation of Ödön von Horvath's Es geht immer besser, besser - immer besser. Ein Tanzvergnügen. He also has quite deliberately echoed the well-known photograph of Brecht at the 1919 Augsburg fair early in Cuilli's career, with a production of Horvath's Casimir and Caroline in 1985, where the setting — in homage to Brecht - represented a complete Oktoberfest theatre, with on-stage Bänkel platform, clowns performing, and wandering spectators. This established his uniquely stylized form of metatheatre.

Ciulli is truly post-modern. What he performs or directs across Asia (in his international "Silk Road" project) or in Germany, are almost exclusively adaptations of classics, whether European or Eastern, rather than original plays - and (as Linda Hutcheon has asserted) adaptation is the sign and definition of the post-modern, particularly in the elements of 1) parody, 2) of pastiche of previous work or other art forms, and 3) of self-referentiality, which in terms of drama and performance signify the play-within-the play, meta-theatre, or overtly revealing the performative nuts and bolts of production techniques, usually hidden beneath the artistic surface. For Ciulli, in itself theatre is a space for dialogue, an instrument for changing the world.

These post-modern qualities are clear in one of his most iconic productions: his staging of Brecht's Dreigroschenpper (itself of course an adaptation of The Beggar's Opera). This was set in a very modernistic 1930s Italian mafia context where, at the wedding of Macheath and Polly, the character of the police chief was forcibly dressed up in a tiger-skin coat and tiger head mask, in a clear echo of circus animals. In this adaptation, gender-bending transforms Brecht's capitalist underworld of murderers ("Mack the Knife") and brothels ("The Song of Sexual Dependency") into a fantasy of sexual politics, where the fortune teller is a woman, dressed as a man, while the three out of the four prostitutes are undisguisedly male in cliché-female ballet dresses, while the single woman has a parody of female makeup, including exaggeratedly big red lips, giving a deliberately clownish impression. Even the brothel "Madame" — acted very recognizably by Ciulli himself in drag contributed to the challenging of gender stereotypes. Indeed the whole production became a literal deconstruction of Brecht, underscoring theatricality by framing the action in a cabaret setting, instead of in mid-19th-century England (on the eve of Queen Victoria's coronation) and presenting Brecht's action as a series of variety acts: Skits separated from each other by songs and farcical clown acts. But however "Post Modern" this may seem to be, every single aspect of this adaptation was traditional, with white hats for the Mafia, the clown make-up and red noses, even the sexual inversions. As such the production became a pastiche of both Circus and of the avant-garde.

In deliberate contrast to the technological illusions created by modern media, the aim of Ciulli's "theatre of images" is to bring out "fissures" in the images on his stage, and thus in the spectator's society, suggesting a world beyond the images. As he has said, "It makes no sense to raise the curtain on a world, one already knows". Ambiguity and contradiction are Ciulli's principles in his visual treatment of dramatic material. So in the 1987 staging of Peter Hanke's Kaspar, the whole world presented is a phanastmorgoria. Handke used the 
central figure of a white-faced clown in traditional white costume — which was undoubtedly what appealed to Ciulli. In his vision the actors present society as macabre puppets with straggling hair, whitened faces and cocaine-chic make-up, or as sinister burocrats in black suits and ties, and dark glasses, but with long Pinocchio noses and tiny clown hats attached with obvious rubber strings.

This circus imagery is given its most extreme form in Ciulli's 2005 production of the $19^{\text {th }}$ century Georg Büchner classic about revolution, Danton's Death, where the whole story (designed for Ciulli's Silk Road) was staged as a travelling circus show, with the actors as performing monkeys, in full monkey masks and band uniforms, sitting in the opening scene on a fairground organ-wagon.

Circus, often dismissed as simply for children, can be seen as a form of total theatre: both physical performance, as well as anti-text; and in its working-class, anti-aesthetic base, automatically presenting a strongly political undercurrent in its anti-establishment style. Even more directly than Ciulli, the leading Canadian avant-garde director, Robert Lepage, has recently turned to clowns and the circus. Indeed, Lepage has increasingly turned to popular forms alongside his avant-garde pieces, having started starting by designing rock tours for Peter Gabriel (1993, 2002), and progressing to collaborations with the Montreal group, Cirque du Soleil. In particular he has mounted mythological shows with Cirque du Soleil, like KA: staged in that most popularist venue, Las Vegas, opening in 2005.

Kà - named for a divine fire that cleanses, either by destroying or illuminating - combines complex automation, pyrotechnics, puppetry, and multimedia projections. As the Los Angeles Times stated, it "may well be the most lavish production in the history of Western theater. It is surely the most technologically advanced" (although even that has been outdone by Lepage's recent lavishly mechanized Wagnerian Ring Cycle at the Met. Circus meets Ex Machina, Lepage's very significantly named Montreal production company. The story of KA is archetypal: royal twins, orphaned by a palace coup; a mythic conflict between evil and good; with the crucial decision being taken by an anthropomorphic forest deity, named Firefly Boy.

In exactly the same way, Lepage's latest collaboration with Cirque du Soleil, the 2011 Totem presents an acrobatic clown show centering on an equally mythic story, the Creation of Life and the Evolution of mankind. Charting the rise from an ocean of life to higher consciousness as spiritual progress, the show combines the standard circus performers - clowns, acrobats, trapeze artists. They go together with the Cirque du Soleil's defining mark: Since the Cirque morally rejects including actual animals as a form of cruelty, they use human performers to represent animals, through costumes and imitative acrobatics. In this case Lepage gives this practice an appropriate mythic significance, by linking the amphibian or simian with the human. There is no dialogue, although music accompanies the activities of the performers. Everything is communicated through gestures and images, together with elaborate lighting effects and scenic elements, with the scene moving from crawling amphibious shapes in underwater light effects at the beginning to human forms and spiritual heights in the twirling and flying acrobats on high wires and trapezes against the star-lit heavens.

\section{Conclusion}

This collaboration between Lepage and Cirque du Soleil, ironically, reinvigorates the writer's earlier view of the avant-garde as ritualistically attempting to return to the source of existence, and combines it with this perception of the avant-garde as a popular movement, using the most basic of performance arts: acrobatics and clowns, here as primitive, frog-like life forms - or in KA as fireflies and forest creatures.

However, the work of both Ciulli and Lepage marks a significant change in the way this circus imagery 
has been used during the avant-garde movement as a whole. In the early part of the previous century, avant-garde borrowings from circus were largely defensive — popular art forms being beneath official notice - and political, in privileging the proletarian over aristocratic aesthetics. In people's new $21^{\text {st }}$ century the links with circus are more professional, and more lavishly spectacular. They also have a different purpose. Ciulli is not only postmodern in his approach. His characteristic deconstruction uses clown imagery to undermine the classical picture of a well-known or traditional play-text. But what it also does is (most obiously with the performing monkeys of Danton's Death) to automatically turn naturalistic characters into comic clichés. In addition, Ciulli defines his productions as a "theatre of images" where the visual is privileged over the verbal or intellectual. In deliberate contrast to the technological illusions created by modern media, the aim of Ciulli's "theatre of images" is to bring out "fissures" in the images on his stage, and thus in the spectator's society, suggesting a world beyond the images. As he has said it makes no sense to raise the curtain on a world, one already knows. Ambiguity and contradiction are Ciulli's principles in his visual treatment of dramatic material, with the result that circus, presented in explicit visual images, ruptures the frame of the play text. Lepage is taking a slightly different line in his collaborations with an actual circus. It is Lepage who has introduced both mechanistic and multimedia staging, as well as indeed story lines to the Cirque du Soleil's performances. The displays of physical acrobatics, or grotesque clowning, transform the icons and stories into performative clichés so that it inevitably reveals the metatheatical nature of the performance.

All this is in a real sense not just post-modern, but post-dramatic. However, Ciulli's work is presented not only in the standard theatre, but as a Western image for Arab and Asian spectators, while Lepage's audiences in Las Vegas where over 1.2 million people have seen KA or the spectators for touring shows like Totem, are literally the populace — in no way an elite — most of whom would have no concept of "Postmodernism". This may be why in the work of both directors postmodern qualities become buried beneath sheer spectacle (KA is reported to have cost $\$ 220$ million to develop). Yet postmodern attributes are still present - uniting the most commercialized style of performance with the contemporary avant-garde; all relying on the completely popular and physical of performance arts: the Circus.

\section{References}

Cf. Prologue to Erdgeist, http://www.gutenberg.org/files/29682/29682-h/29682-h.htm.

Cf. A History of German Theatre, ed. Simon Williams \& Maik Hamburger, Cambridge: Cambridge University Press, 2008.187.

John Fuegi, Bertolt Brecht: Chaos, According to Plan. Directors in Perspective (ed. Christopher Innes) Cambridge: Cambridge University Press, 1987.

Linda Hutcheon, A Poetics of Post-Modernism: History, Theory, Fiction, London: Routledge, 1988, and A Theory of Adaptation,

New York: Routledge, 2006.

Roberto Ciulli, cit. Frank Raddatz, Botschafter der Sphinx. Zum Verhältnis von Ästhetik und Politik beim

Theater an der Ruhr Verlag Theater der Zeit, 2006, 98.

Mark Swerd, Los Angeles Times, 5 February 2005.

Mathew Hayes, The Globe and $\quad$ Mail, 29 April

http://www.theglobeandmail.com/arts/theatre-and-performance/robert-lepage-cirque-du-soleil 